Creative commons User License: CC BY-NC-ND

Abstracted by: EBSCOhost, Electronic Journals Service (EJS),

Google Scholar, Directory of Open Access Journals (DOAJ),

Journal Seek, Scientific Commons,

Food and Agricultural Organization (FAO), andCABI
Journal of Agricultural Extension

Vol. 20 (1) June, 2016

ISSN(e): 24086851; ISSN(Print); 1119944X

http://journal.aesonnigeria.org

http://www.ajol.info/index.php/iae

Email: editorinchief@aesonnigeria.org

\title{
Perception of Stakeholders to the Proposed Ban on Cow Hide Consumption in Ogun State, Nigeria \\ Http://dx.doi.org/10.4314/jae.v20i1.15
}

\section{Tijani S.A.}

Department of Agricultural Extension and Rural Development, Faculty of Agriculture and Forestry, University of Ibadan, Ibadan Email: tsarafat@yahoo.com; Phone:+2348051370802

Ajayi 0.O.

Department of Agricultural Extension and Rural Development, Faculty of Agriculture and Forestry, University of Ibadan, Ibadan. Email: olabisiajayi73@yahoo.com; Phone: +2348065756607

\section{Abstract}

The study examined the perception of stakeholders to a ban on cow hide consumption in Ogun State. Purposive and random samplings were used to select 150 respondents. Data was collected using interview schedule and analysed with descriptive and inferential statistics. Results reveal that majority $(60.7 .0 \%)$ of the respondents were female, within the age of 36-42years, married (75.3\%) and had secondary education (42.7\%). Respondents had low knowledge of the proposed ban (58.0\%); $56.0 \%$ had high awareness of the possible benefits but $56.0 \%$ had negative perception towards the proposed ban. There was significant correlation between sources of information ( $r=0.279, p=0.001)$, level of knowledge $(r=0.281, p=0.001)$, constraints that respondents may face from the ban ( $r=0.165, p=0.043)$, awareness of the possible benefits $(r=0.461, p=0.000)$ and respondent's perception to the proposed ban on cow hide consumption. Since more than half of the respondents had negative perception despite their awareness of benefits, concrete efforts need to be taken to improve livestock production in order to cater for leather industries and consumption.

Keywords: Cow hide consumption, cow hide value chain, ponmo

\section{Introduction}

Agriculture is the major path to economic growth and sustainability. Large regional and continental markets, as well as the ever increasing world market exist for the reaping of the potentials that agriculture can offer any economy.

Livestock farming is one of the major agricultural activities in the country and contributing towards achieving development goals of the National Growth and Reduction of Poverty (NSGRP). The livestock industry contribution to the agricultural gross domestic product is about $13 \%$, and also contributes $4.0 \%$ and $4.7 \%$ of the national gross domestic product in 2009 and 2008, respectively. However, the contribution of the livestock industry to the economy is not limited to its share in the total GDP but also plays other roles such as supply of food products of animal origin thus contributing to food security, converts forages and crop residues into edible products, source of income and employment, contributes in crop farming as a source 
Creative commons User License: CC BY-NC-ND

Abstracted by: EBSCOhost, Electronic Journals Service (EJS),

Google Scholar, Directory of Open Access Journals (DOAJ),

Journal Seek, Scientific Commons,

Food and Agricultural Organization (FAO), andCABI
Journal of Agricultural Extension

Vol. 20 (1) June, 2016

ISSN(e): 24086851; ISSN(Print); 1119944X

http://journal.aesonnigeria.org

http://www.ajol.info/index.php/iae

Email: editorinchief@aesonnigeria.org

of manure and draught power and fulfills cultural roles in livestock farming communities.

Aside serving as a source of protein, hides and skin when processed, hide and skin have a lot of international demand where they are used in the production of leather products like shoes, bags, watch straps, belts, etc. Nigeria produces one of the best hides and skin in the world and in order to encourage local processing of hides and skin, development of related industries and employment generation, the Nigerian government placed a ban on the export of raw hides and skin. This ban has encouraged the establishment of local tanneries who are constantly in need of raw hides and skin for processing, hence creating supply opportunity for interested marketers.

Hides commonly known as ponmo, is the skin of cow that has been processed to look similar to beef. There are two main known varieties of ponmo, based on their mode of preparation and colour. The first involves the soaking of the animal hide in hot water after which a razor blade is used to shave off the hair. Cow hide prepared in this method comes out as a creamy-white colour. On the other hand, the other variety, which is brown in colour, is prepared by subjecting the animal hide to an amount of heat in order to burn off the hides. After this process, the hide is then washed severally and then softened through prolonged boiling.

The popular cow hide staple is known as ponmo by the Yorubas, ganda by the northerners, akpupoanu by the Igbos, ano by the Igalas and ohian by the Edos. The high frequency of cow hide (ponmo) intake has made it a mass-consumption product, the consequence of which is the decrease in the supply of hides for shoe and leather related cottage industries. When one considers the fact that the biological value of the protein obtainable from ponmo is suspect because leather is almost pure collagen (which contains little or no nutrients), then why should the raw material for making shoes and bags be consumed? It is suggested that marketers of hides and the nation as a whole stand to benefit better from its sale or export than the nutrition gain attached to the consumption of cow hide.

There is a warning against the consumption of ponmo because some of the animals slaughtered have hide diseases and because of such ailment, animals are sometimes treated by way of injection with chemicals (vaccination). Often times, these chemicals do not complete their life cycle (Incubation) wherein they peter out from the hide of the animals before they are slaughtered. So, if such hide is consumed as ponmo, there is tendency of consuming part of the chemicals from the innocuous-looking ponmo because the hide of the animals retains most of the harmful substances. Additionally, the prohibitive cost of firewood which is used in burning off the hair from the hide has made many to resort to all manners of combustible materials including disused plastics, rubber as well as other harmful but flammable by-products. As the fire burns, the combusting wood, gas or charcoal emit chemicals known as polycyclic aromatic hydrocarbons (PAHs), which find their way into the food and contaminates it. Exposure to PAHs is known to cause hide, stomach and liver cancer. More so, in an effort to promote the activities of local cottage industries, the federal government of Nigeria proposed a ban on the 
Creative commons User License: CC BY-NC-ND

Abstracted by: EBSCOhost, Electronic Journals Service (EJS),

Google Scholar, Directory of Open Access Journals (DOAJ),

Journal Seek, Scientific Commons,

Food and Agricultural Organization (FAO), andCABI
Journal of Agricultural Extension

Vol. 20 (1) June, 2016

ISSN(e): 24086851; ISSN(Print); 1119944X

http://journal.aesonnigeria.org

http://www.ajol.info/index.php/iae

Email: editorinchief@aesonnigeria.org

consumption of cow hide. However, it becomes imperative to assess the marketer's/sellers' perception on the proposed ban. The specific objectives were to:

1. describe personal characteristics of the stakeholders in cow hide value chain;

2. identify sources of information of the respondents on the proposed ban;

3. examine respondents' knowledge of the proposed ban on cow hide consumption of cow hide;

4. ascertain the expected benefits derivable from the proposed ban on cow hide consumption;

5. identify the possible constraints that the respondents may face from the proposed ban; and

6. evaluate the perception of the respondents on the proposed ban on cow hide

\section{Methodology}

The research was carried out in Ogun state, Nigeria. The state lies within longitudes $3.0^{\circ}$ and $5.0^{\circ}$ east and latitudes $6.2^{\circ}$ and $7.8^{\circ}$ north. Ogun state has a land area of 16.409.28 square kilometers and represents less than two percent of Nigeria's landmass, with a population of approximately 3.73 million and 20 local government areas (LGAs) (The National Population Commission, 2006). The population of the study comprised processors, marketers/sellers and consumers of cow hide in Ogun state. Purposive sampling technique was used to select Abeokuta and ljebu-igbo LGAs because of concentration of stakeholders in the cow hide value chain. One hundred and fifty (150) randomly selected respondents were interviewed, using a well-structured questionnaire. In each of these two cities, $40 \%$ of 63 (30 and 33) processors and 98 (48 and 50) retailers were chosen giving rise to a total of 25 processors and 39 retailers while the remaining 86 respondents were consumers. Respondents were interviewed at processing sheds, markets, shops and canteens. Knowledge of ban on ponmo consumption was measured as: correct $=1$ and wrong = 0 , mean was generated and used to categorise into high and low knowledge Sources of information were based on yes $=1$ and no $=0$. Awareness of possible benefits: yes $=1$ and no $=0$. Constraint was measured using: not severe $=0$, severe $=1$ and very severe $=2$. and this was ranked based on the highest mean Stakeholders' perception was measured using a Likert type scale of Strongly Agree $(S A)=5$, Agree $(A)=4$, Undecided $(U)=3$, Disagree $(D)=2$, and Strongly disagree $(S D)=1$ for positivelyworded statements and vice versa for negative statements. The mean score was obtained and used to categorise the perception of the stakeholders to the proposed ban as positive or negative. 
Creative commons User License: CC BY-NC-ND

Abstracted by: EBSCOhost, Electronic Journals Service (EJS),

Google Scholar, Directory of Open Access Journals (DOAJ),

Journal Seek, Scientific Commons,

Food and Agricultural Organization (FAO), andCABI
Journal of Agricultural Extension

Vol. 20 (1) June, 2016

ISSN(e): 24086851; ISSN(Print); 1119944X

http://journal.aesonnigeria.org

http://www.ajol.info/index.php/iae

Email: editorinchief@aesonnigeria.org

\section{Results and Discussion}

\section{Personal Characteristics of Respondents}

Table 1 shows that $67.3 \%$ of the respondents fell between the age range of 29 and 42 years (mean=36 years). It implies that majority of them were young and still possessed enough strength, vigour and vitality to play their roles actively in the cow hide value chain. Likewise, majority $(60.7 \%)$ of them were females, which is indicative of the growing involvement of women in small-scale enterprises such as ponmo processing and marketing, and the rise in their contribution to economic life and share in the labour force (Sani and Sani, 2005). Majority (75.3\%) were married with $53.3 \%$ having household sizes of between 5 - 8 persons. This stems from commitment and responsibility often associated with married people (Erbugh et al., 2007), but persons in their households can serve to provide family labour in the value chain (Sule, Ogunwale and Atala, 2002). It was also revealed that $80 \%$ of the respondents had a working experience of between $1-9$ years (mean $=4.8$ years), which is ample enough to influence their perception positively or negatively on the proposed ban.

\section{Sources of Information on Proposed Ban of Cow Hide Consumption}

Table 2 shows that radio (57.3\%) was the ultimate source of information on the proposed ban on cow hide consumption (Table 2). This corroborates the finding of Eniola et al (2010) that radio is the main source of getting informed due to its accessibility and the erratic nature of power supply in the country. The popularity of radio as an information source can thus be utilized by relevant authorities in order to promote change. Television (56.0\%), friends $(54.7 \%)$ along with customers $(46.0 \%)$ were also vital sources of information, while newspaper (36.7\%) was regarded as the least important information source. 
Creative commons User License: CC BY-NC-ND

Abstracted by: EBSCOhost, Electronic Journals Service (EJS),

Google Scholar, Directory of Open Access Journals (DOAJ),

Journal Seek, Scientific Commons,

Food and Agricultural Organization (FAO), andCABI
Journal of Agricultural Extension

Vol. 20 (1) June, 2016

ISSN(e): 24086851; ISSN(Print); 1119944X

http://journal.aesonnigeria.org

http://www.ajol.info/index.php/jae

Email: editorinchief@aesonnigeria.org

Table 1: Distribution of respondents by personal characteristics

\begin{tabular}{lc}
\hline Age (Years) & 13.3 \\
$15-28$ & 67.3 \\
$29-42$ & 18.7 \\
$43-56$ & 0.7 \\
$\geq 57$ & \\
Sex & 39.3 \\
Male & 60.7 \\
Female & \\
& \\
Marital status & 18.7 \\
Single & 75.3 \\
Married & 3.4 \\
Divorced & 2.7 \\
Widowed & \\
Education & 6.7 \\
No formal education & 10.7 \\
Primary education & 42.7 \\
Secondary education & 40.0 \\
Tertiary education & \\
Household size & 45.3 \\
$1-4$ & 53.3 \\
$5-8$ & 1.4 \\
$\geq 9$ & \\
Year of work experience & 80.0 \\
$\leq 9$ & 17.3 \\
$10-19$ & 2.7 \\
$20-29$ &
\end{tabular}

Source: Field survey, 2015. 
Table 2: Respondents sources of information on proposed ban on cow hide consumption

\begin{tabular}{lc} 
Source of information & Percenta \\
\hline Radio & $57.3^{*}$ \\
Television & $56.0^{*}$ \\
News paper & 36.7 \\
Internet & 46.7 \\
Friends & $54.7^{*}$ \\
Customers & 46.0
\end{tabular}

Source: Field survey, 2015; multiple responses

\section{Knowledge of Proposed Ban on Cow Hide Consumption}

The level of knowledge of the respondents on the proposed ban on cow hide consumption indicates that $58.0 \%$ possessed low knowledge. This result gives a pointer to how enlightened they are which is likely to make them exhibit a negative disposition to the proposed ban. Proper enlightenment becomes a key to improving their knowledge, to which Lewis and Leach (2006) noted that additional knowledge enhances understanding and influences the ability to identify key issues.

Table 3: Respondents knowledge level of proposed ban on cow hide consumption

\begin{tabular}{lll}
\hline Category & Percentage & Mean \\
\hline Low (13-20.3) & 58.0 & 26 \\
High (20.4-26) & 42.0 &
\end{tabular}

Source: Field survey, 2015.

Expected Benefits Derivable from Proposed Ban on Cow Hide Consumption

Respondents were aware that a ban will not only lead to a reduction in the price of leather products $(67.3 \%)$, but also increase in the quality of locally made shoes (75.3\%). If a ban is placed on cow hide consumption, more hides and skins will be available for local tannery industries for the production of leather products hence increasing product quality and price reduction. Also $66.7 \%$ of them stated that it will lead to the creation of more job, while $82.0 \%$ attested it will boost the economy of the country through foreign exchange earnings from the export of hides and skins. It follows that value addition of hides and skin has the potential of improving income generation (Wayaa and Kagunyu, 2008) 
Table 4: Distribution of respondents by expected benefits from proposed ban on cow hide consumption

\begin{tabular}{ll}
\hline \multicolumn{1}{c}{ Statements } & $\begin{array}{c}\text { Yes } \\
\%\end{array}$ \\
\hline $\begin{array}{ll}\text { Reduction in the price of leather products e.g bags } \\
\text { Creation of more job opportunities }\end{array}$ & 67.3 \\
Improvement in Nigeria economy through foreign & 66.7 \\
exchange earnings from the export of leather & $82.0^{*}$ \\
Increase in the quality of local made shoes & $75.3^{*}$ \\
Processing cow hide for leather industries is easier and & 46.7 \\
\hline
\end{tabular}

Source: Field survey, 2015

\section{Perceived Constraints to Proposed Ban on Cow Hide Consumption}

Table 5 shows that limited accredited market source $(50.0 \%)$, presence of many middlemen in the value chain (52.0\%) and loss of income and employment opportunities $(36.0 \%)$ as well as infiltration of poorly processed cow hide in the market $(36.7 \%)$ were the perceived severe constraints to the proposed ban on cow hide consumption.

Table 5: Perceived constraints to the proposed ban on cow hide consumption

\begin{tabular}{|c|c|c|}
\hline Constraints & Mean & Rank \\
\hline $\begin{array}{l}\text { Infiltration of poorly processed cow } \\
\text { hide }\end{array}$ & 1.61 & $5^{\text {th }}$ \\
\hline Limited accredited market source & 1.67 & $3^{\text {rd }}$ \\
\hline $\begin{array}{l}\text { Income and employment might be } \\
\text { lost }\end{array}$ & 2.07 & $1^{\text {st }}$ \\
\hline Presence of too many middlemen & 1.84 & $2^{\text {nd }}$ \\
\hline High transaction levies & 1.62 & $4^{\text {th }}$ \\
\hline Location of collection centre & 1.47 & $6^{\text {th }}$ \\
\hline
\end{tabular}

\section{Perception of Proposed Ban on Cow Hide Consumption}

Table 6 indicates that most of respondents (56.0\%) had a negative perception to the proposed ban on cow hide consumption. Despite their level of awareness of the possible benefits inherent in the proposed ban, most of them were still not in favour of the proposed action. This disposition is not far-fetched and may stem from the perspective that some of the stakeholders were involved in cow hide-related activities because it is a source of livelihood to them. But to others their consumption of ponmo, despite its low nutritional value, is a cheaper alternative to other sources of 
animal flesh which can be used to "exercise the mouth" during meal time. A possible course of action in an attempt to generate a positive perception towards the proposed would therefore need to address the concern of the various stakeholders.

Table 6: Distribution of respondents by level of perception to proposed ban on cow hide consumption

\begin{tabular}{lll}
\hline Category & Percentage
\end{tabular}

Source: Field survey, 2015

\section{Relationship Between Selected Variables and Perception to the Proposed Ban on Cow Hide Consumption}

Table 7 shows a significant relationship between years of working experience and perception of the proposed ban on cow hide consumption ( $r=0.166, p \leq 0.05)$. Working experience serving as a predictor of the proposed ban on cow hide consumption means the number of years a role player is involved in the processing or retailing or consuming of cow hide is capable of influencing his or her perception positively or negatively towards the proposed ban on cow hide. i.e stakeholders with long years of experience will have negative perception to the proposed ban due to the fear of losing their source of livelihood and essential part of consumers" diet (food). However, if long years of working experience has additional benefits to offer then stakeholders might have positive perception to the proposed ban.

Similarly, a significant relationship existed between respondents' sources of information and perception to the proposed ban on cow hide consumption $(r=0.279$, $p \leq 0.05)$. Regular access to information from radio, television and friends can effectively change people's impression and perception to the proposed ban (Rezvanfa et al, 2007). It implies that enlightenment can go a long way in influencing perception.

A significant relationship was observed between respondents' knowledge and perception to the proposed ban on cow hide consumption $(r=0.281, p \leq 0.05)$. This means that the respondents' knowledge can give an indication of how they view the proposed ban on the product. Someone who understands the nutritional value and the health risk associated with the consumption of ponmo may favour its proposed ban on the one hand, and someone with little or no knowledge about the product may be averse to its ban on the other hand. Okwoche et al (2012) observed that education (knowledge) is crucial in the adoption of change. 
Benefits expected and perception of the proposed ban on cow hide consumption were also significantly related $(r=0.461, p \leq 0.05)$. This implies that the benefits that will result subsequent to the ban can influence their perception positively or negatively hence determining their willingness to accept or reject any proposed ban.

Table 6: Correlations between selected variables and perception of proposed ban on cow hide consumption

\begin{tabular}{ll}
\hline Variable & $\mathbf{r}-\mathbf{v a l u e}$ \\
\hline Working experience & $0.166^{*}$ \\
Knowledge & $0.281^{*}$ \\
Information & $0.279^{*}$ \\
Benefit & $0.461^{*}$ \\
\hline${ }^{*} \mathrm{P} \leq 0.05$. Source: Field survey, 2015.
\end{tabular}

\section{Conclusion and Recommendation}

Most of the stakeholders in the cow hide value chain in the study area had negative perceptions to the ban which can be attributed to their low level of knowledge of the proposed ban on cow hide consumption. Effort should be made to identify major / large scale processor who will be motivated (through incentives e.g loan or advance payment to start) to sell their products to the designated collection center for the leather industries. This will make it unavailable/inaccessible to the retailer and consumers. Policy should be formulated to increase other animal products such as meat, egg and fish to serve as competitive alternatives to cow hide consumption among consumers. Above all, proper enlightenment through mass media should be ensured in order to enhance the understanding of the proposed ban.

\section{References}

Adebayo, K. (2006). Rural development Nigeria: Episodic drama, soap opera and comedy. University of Agriculture Abeokuta, Alumni Association Lecture Series No 6.

Erbaugh J.M., Donnermeyer, J and Amujal, M (2007) Assessing the impact of farmer field school participation on IPM pdoption in Uganda. In: AIAEE 2007 Proceedings of the 23rd Annual Conference "Internationalizing with Cultural Leadership 20-24 May 2007, Montana, United States of America. Feder, G., Just, R. \& Zilberman, D. (1985) eds.

Leach, L. and Wilson R. T. (2009). Higher value addition through hides and skins. FAO diversification booklet No.8 FAO, Rome.

Lewis Jenny and Leach John (2006). Discussion of socio scientific issues: The role of science knowledge International Journal of Science Education vol. 28, no. 11 , p. $1267-1287$ 
Creative commons User License: CC BY-NC-ND

Abstracted by: EBSCOhost, Electronic Journals Service (EJS),

Google Scholar, Directory of Open Access Journals (DOAJ),

Journal Seek, Scientific Commons,

Food and Agricultural Organization (FAO), andCABI
Journal of Agricultural Extension

Vol. 20 (1) June, 2016

ISSN(e): 24086851; ISSN(Print); 1119944X

http://journal.aesonnigeria.org

http://www.ajol.info/index.php/jae

Email: editorinchief@aesonnigeria.org

Okwoche, V. A., Asogwa, B. C. and Obinne, P.C. (2012). Evaluation of agricultural credit utilization by cooperative farmers in Benue State of Nigeria, European Journal of Economics, Finance and Administration Science. Vol. 47, pp18-27.

Rezvanfar, A., Moradnezhai, H, and Vahedi, M. (2007). Information needs of farm women related to during farming and home management Ilam State of Iran. Livestock Research for Rural Development, 19(8).

Sani, M.H. and S. Sani, 2005. The marketing of sorghum in selected markets in the Eastern part of Kogi State, Nigeria. Yankari J., 2: 114-122.

Sani, M.H. and S. Sani, 2005. Market economic analysis of selected Fadama crops: Tomato, onion, okra, lettuce and cabbage in Kogi State, Nigeria. Yankari J., 2: 107-113.

Sule, A.M., Ogunwale, S.A. and Atala, T.K. (2002). Factors affecting adoption of fishing innovation among fishing entrepreneurs in Jebba Lake Community. In: $\quad$ T.A. Olowu (ed.), Journal of Agricultural Extension. Vol.6, pp. 48- 60.

Wayua F O and Kagunyu A (2008) Empowering pastoralists through local options for livelihood diversification: hides and skins value addition and marketing in Northern Kenya. Paper presented at the Animal Production Society of Kenya (APSK) 2008 Annual Symposium, "Empowering Livestock keepers through Growth in Agribusiness", KARI-Katumani, 7-9 May 2008. 